\title{
Knowledge and practice regarding dengue fever among primary health care center patients at Makkah
}

\author{
Hossam Hussen Hijazy ${ }^{1}$, Sadeq Anees Uddinserdar ${ }^{2}$, Rami lbrahim Alamri ${ }^{3}$, Rayan Abdurrahman Alharbi ${ }^{4}$, Moataz \\ Salahaldeen Aljawi ${ }^{5}$, Hamad Nasser Alshareef ${ }^{6}$, Motaz Hussain Alsamli ${ }^{7}$, Hosam Wahid Wali ${ }^{8}$, NahlahTulat \\ Haddad $^{9}$
}

${ }^{1}$ Family Medicine specialist, Public Health in Makkah, KSA

${ }^{2}$ Senior public Health specialist, Public Health in Makkah

${ }^{3}$ Health and hospital admin, Public Health in Makkah

${ }^{4}$ General Practitioner, Public Health in Makkah

${ }^{5}$ Nursing Technician, Public Health in Makkah

${ }^{6}$ Nursing technician, Public Health in Makkah

${ }^{7}$ Nursing Technician, Public Health in Makkah

${ }^{8}$ General Practioner, Public Health in Makkah, KSA

${ }^{9}$ Family Medicine Specialist, Al Diafah Primary Health Care, KSA

Correspondence Author: Hossam Hussen Hijazy Family Medicine specialist, Public Health in Makkah, KSA

E-mail: Hossamoree@gmail.com

Received date: 10 January 2019, Accepted date: 25 February 2018, Online date: 28 February 2019

Copyright: (C) 2019 Hossam Hussen Hijazy et al. This is an open-access article distributed under the terms of the Creative Commons Attribution License, which permits unrestricted use, distribution, and reproduction in any medium, provided the original author and source are credited.

\begin{abstract}
Background: Dengue fever is a rapidly emerging infection throughout the tropics and subtropics with extensive public health burden. The aim of this study was to assess primary health care setting patients' knowledge and practices regarding dengue fever.

Methods: Cross sectional study was used. A 47-item questionnaire of dengue knowledge and practices were developed and administered to primary healthcare center patients, KSA.

Results: The results showed that $(43.5 \%)$ of patients aged from $45-59$ years, $(52.8 \%)$ were male, $(53.5 \%)$ married, $(51 \%)$ take their knowledge from the health care professionals. The data indicated that $(58.5 \%)$ of patients have a high level of knowledge and $(68 \%)$ have average level of practices regarding prevention of dengue fever.

Conclusion: Patients demonstrated a high level of knowledge of dengue, but additional training regarding prevention practices is needed. Interventions should not only focus on increasing knowledge, but also encourage review of the WHO Dengue Guidelines, avoidance of presumptive self-medication, and recognition of dengue as a major health problem.
\end{abstract}

Keywords: Dengue fever, knowledge, practice, primary health care patients

\section{INTRODUCTION}

Dengue virus (DENV) infection has globally become a major public health concern since the incidence of dengue fever (DF) has increased more than 30-fold over the last five decades and the disease is now endemic in 128 countries. According to a recent study, 390 million DENV infections are estimated to occur per year; over three times more than previous estimates by the World Health Organization (WHO) had suggested (Lee et al., 2011; WHO/TDR (2009); Brady et al., 2012; Bhatt et al., 2013).

Dengue is transmitted in humans by two species of Aedes mosquitoes namely, Aedes aegypti (principal vector) and Aedes aldopictus. Although infection with one dengue serotype confers lifetime immunity against reinfection by the same serotype, there is no evidence of cross-immunity. Therefore, it is possible for one to be infected with dengue fever several times during one's lifetime (Shuaib et al.,2010; CDC, 2008; Hales et al., 2002; Pai et al., 2005; Leong et al., 2007; WHO, 2009; Heyman et al., 2008).

Dengue infection may cause fever, headache, abdominal pain, rash, muscle aches, pain in the eyes and bone pain (hence 'break-bone fever'). Infection with additional dengue serotypes increases the risk of hemorrhagic disease, resulting in severe mucosal and gastrointestinal bleeding, petechial skin hemorrhage, hepatomegaly, and circulatory disturbances, hypovolemia, and potentially death (Handel et al., 2016; Nalongsack et al., 2009; Halstead et al., 2007; Hotez et al., 2009).

Dengue fever is a major arbovirus-borne infectious disease in tropical and subtropical regions of the world. The disease is generally mild and self-limited, but some patients may develop a severe form of infection such as dengue hemorrhagic fever/dengue shock syndrome, which often leads to death. Currently, there is no vaccine available against dengue virus. The major 
Citation: Hossam Hussen Hijazy, Hosam Wahid Wali, NahlahTulat Haddad, Sadeq Anees Uddinserdar, Rami lbrahim Alamri, Rayan Abdurrahman Alharbi, Moataz Salahaldeen Aljawi, Hamad Nasser Alshareef, Motaz Hussain Alsamli. Knowledge and practice regarding dengue fever among primary health care center patients at KSA. Australian Journal of Basic and Applied Sciences., 13(2): 87-94. DOI: 10.22587/ajbas.2019.13.2.11

determinants of dengue control are vector eradication, early case recognition, and adequate clinical management (Tzong- Shiann et al., 2013).

It is generally an acute febrile illness, with severe headache, myalgia, arthralgia, and rashes. Leucopenia and thrombocytopenia may also be observed (Itrat et al., 2008). Reliably identifying dengue patients early in their clinical bn course could direct patient management and reduce the transmission of dengue virus in a community. Timely identification of dengue infection would potentially enable HCPs to prevent additional cases among close contacts by urging patients with a positive dengue screening test to use personal protection measures against mosquito bites (Tzong-Shiann et al., 2013; Malavige et al., 2004; Biswas et al., 2012; Premaratna et al., 2009; Ramos et al., 2009; Chang et al., 2009; Laoprasopwattana et al., 2012)

Recent outbreaks of dengue in Egypt and the paucity of relevant studies on knowledge, and practices regarding dengue transmission and infection necessitated the development of the study. Further, although investments have been made in media campaigns to increase awareness about dengue by the government, non-governmental settings, no assessment has been conducted to determine the impact of such interventions or to identify gaps in knowledge and practice regarding dengue infection (Shuaib et al.,2010)

\section{The aim of the study:}

The aim of this study was to assess primary health care setting patients' knowledge and practices regarding dengue fever.

\section{RESEARCH QUESTION:}

Design:

What are the primary health care setting patients' knowledge and practices regarding dengue fever?

Setting:

The prospective cross-sectional study design was used in carrying out of this study.

Subjects:

The Convenience sample was selected to include primary health care setting patients' who aged from 19-60 years of age and their total number was 200 patients.

Tools of the study:

The tool was designed to collect the necessary data and developed by the researchers after a review of the literature.

The tool I: PHC patients' knowledge and practices regarding dengue fever structured interview questionnaire:

It included five parts as follows:

Part one: Patient's sociodemographic characteristics:

This part consisted of data about the patient's age, sex, marital status, level of education, religion, income, and sources of information.

Part two: Knowledge about signs and symptoms of dengue fever:

Include items that determine the patient's knowledge about the clinical manifestations of dengue fever. This part contains 9 questions.

\section{Part three: Knowledge about the mode of transmission:}

This part explains the patient's knowledge about dengue fever mode of transmission, causative agent. It consisted of 15 closed-ended questions.

Part four: Knowledge regarding management of dengue fever:

This part assesses the patient knowledge about the dengue fever management approaches as rest, fluid replacement. It consisted of five questions.

\section{Part five: Practices regarding prevention of dengue fever:}

This part concerned the preventive practices against Dengue fever e.g. methods used to reduce breeding sites, and reduce potential human-mosquito contact (repellents, bed nets, and window screens).it composed of 18 practices.

Administrative approval was obtained from the responsible persons. A pilot study was carried out before starting of data collection on $(10 \%)$ of the study period for the purpose to test the clarity, completeness, and to determine the time involvement. According to the results of the pilot study, the needed modification, omissions, and/or additions were done. The researcher interviewed each participated patient individually to obtain the necessary information. The actual work started by meeting the patient, the researcher firstly introduced self to them and gave them a complete background about the study. The researcher gave patient (who can read and write), the sheet which was pre-designed in Arabic language and stay with them to clarified any question vague to them or to read the sheet if the patient is unable to read it. The sheet required about 15-20 minutes for filling it.

The patients have ethical rights to agree or refuse to participate in the study. Consent to participate in the study was secured orally and informed that the information obtained will be confidential and used for the purpose of the study. Data were analyzed using the statistical package for social science (SPSS) version 20.0 (Windows Microsoft). Data were presented using descriptive statistics in the form of frequencies and percentages for qualitative variables, means and standard deviations for quantitative variables. Quantitative continuous data were compared using Chi. Square to determine significance for the nonparametric variable. Probability (p-value) less than 0.05 was considered significant.

\section{RESULTS}

Table (1) shows that less than half of patients (43.5\%) were aged from 45-59 years of age, while approximately one-third of patients (32.3\%) aged from 30- 44 years of age. Concerning sex, more than half of the patients (52.8\%) were male. Regarding marital status, more than half of the patients (53.5\%) were married. As for educational level, this table reveals that approximately 
Citation: Hossam Hussen Hijazy, Hosam Wahid Wali, NahlahTulat Haddad, Sadeq Anees Uddinserdar, Rami lbrahim Alamri, Rayan Abdurrahman Alharbi, Moataz Salahaldeen Aljawi, Hamad Nasser Alshareef, Motaz Hussain Alsamli. Knowledge and practice regarding dengue fever among primary health care center patients at KSA. Australian Journal of Basic and Applied Sciences., 13(2): 87-94. DOI: 10.22587/ajbas.2019.13.2.11

one-third of patients (31.5\%) were primary educated followed by illiterate (24\%), secondary (23\%) and university (20.8\%). Regarding income, more than half of the patients (59.3\%) had more than 5000 SR month

ly. Concerning the sources of knowledge about dengue fever, this table shows that approximately half of the patients (51\%) take their knowledge from health professionals, followed by TV in $(22.5 \%)$ of patients.

Table 1: frequency distribution according to sociodemographic characteristics:

\begin{tabular}{|c|c|c|}
\hline & $\mathbf{N}$ & $\%$ \\
\hline \multicolumn{3}{|l|}{ Age } \\
\hline $15-29$ years & 60 & 15.0 \\
\hline $30-44$ years & 129 & 32.3 \\
\hline 45-59 years & 174 & 43.5 \\
\hline More than 60 years & 37 & 9.3 \\
\hline \multicolumn{3}{|l|}{ Sex } \\
\hline Female & 189 & 47.3 \\
\hline Male & 211 & 52.8 \\
\hline \multicolumn{3}{|l|}{ Marital status } \\
\hline Single & 83 & 20.8 \\
\hline Married & 214 & 53.5 \\
\hline Widow & 42 & 10.5 \\
\hline Divorced & 61 & 15.3 \\
\hline \multicolumn{3}{|l|}{ Educational level } \\
\hline Illiterate & 96 & 24.0 \\
\hline Primary & 126 & 31.5 \\
\hline Secondary & 95 & 23.8 \\
\hline University & 83 & 20.8 \\
\hline \multicolumn{3}{|l|}{ Income } \\
\hline Less than $5000 \mathrm{SR}$ & 163 & 40.8 \\
\hline More than 5000SR & 237 & 59.3 \\
\hline \multicolumn{3}{|c|}{ Sources of knowledge about dengue fever } \\
\hline TV & 90 & 22.5 \\
\hline Health professionals & 204 & 51.0 \\
\hline Neighbors & 24 & 6.0 \\
\hline Loud speakers & 68 & 17.0 \\
\hline Family & 14 & 3.5 \\
\hline
\end{tabular}

Table (2) shows that more than two third of patients (67.8\%) have a high level of knowledge about signs and symptoms of dengue fever. Regarding knowledge about mode of transmission and management of dengue fever, more than half of patients (51.3\%) have a high level of knowledge followed by (47.5\%) of patients have an average level of knowledge. Regarding the patients' total level of knowledge about dengue fever, about (58.5\%) have a high level followed by $(41.5 \%)$ have an average level of knowledge. Regarding practices about prevention of dengue fever, this table shows that more than two-thirds of patients (68\%) have an average level of knowledge about prevention practices followed by one-fifth of patients (20\%) have a weak level of knowledge.

Table 2: distribution of patients' knowledge and practices about dengue fever:

\begin{tabular}{|l|l|l|l|l|l|l|l|l|}
\hline & \multicolumn{3}{|l|}{ Weak } & \multicolumn{2}{l|}{ Average } & \multicolumn{2}{l|}{ High } & \multicolumn{2}{l|}{ Score } \\
\cline { 2 - 10 } & $\mathbf{N}$ & $\mathbf{\%}$ & $\mathbf{N}$ & $\mathbf{\%}$ & $\mathbf{N}$ & $\mathbf{\%}$ & Range & Mean \pm SD \\
\hline $\begin{array}{l}\text { Knowledge about signs and symptoms } \\
\text { of dengue fever }\end{array}$ & 9 & 2.3 & 120 & 30.0 & 271 & 67.8 & $6-18$. & $14.278 \pm 2.275$ \\
\hline Knowledge about mode of transmission & 5 & 1.3 & 190 & 47.5 & 205 & 51.3 & $12-30$. & $22.518 \pm 3.477$ \\
\hline $\begin{array}{l}\text { Knowledge regarding management of } \\
\text { dengue fever }\end{array}$ & 11 & 2.8 & 189 & 47.3 & 200 & 50.0 & $3-10$. & $7.470 \pm 1.326$ \\
\hline Total knowledge & 1 & 0.3 & 165 & 41.3 & 234 & 58.5 & $25-56$. & $44.265 \pm 4.797$ \\
\hline $\begin{array}{l}\text { Practices regarding prevention of } \\
\text { dengue fever }\end{array}$ & 80 & 20.0 & 272 & 68.0 & 48 & 12.0 & $7-29$. & $17.628 \pm 3.808$ \\
\hline
\end{tabular}




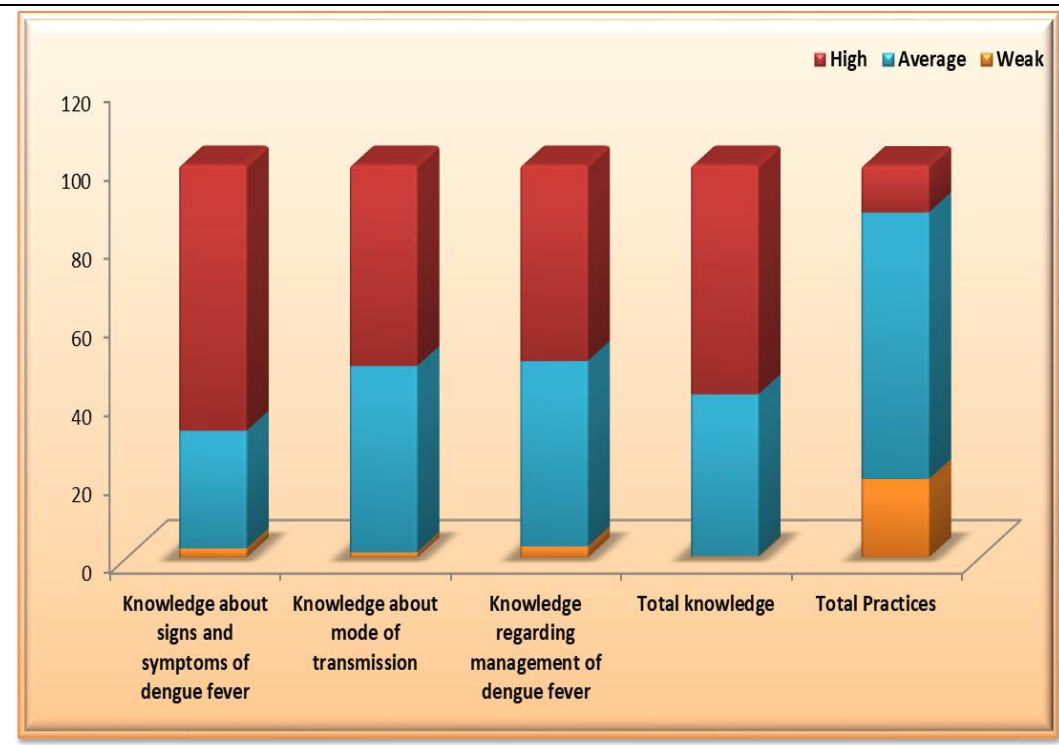

Figure 1: Distribution of patients' level of knowledge about dengue fever

Table (3) shows that there is a statistically significant correlation between total knowledge about signs, symptoms, mode of transmission, management of dengue fever and practices regarding prevention of dengue fever with $\mathrm{P}=0.001$

Table 3: Correlation between knowledge and practices about dengue fever

\begin{tabular}{|l|l|l|}
\hline \multirow{2}{*}{} & \multicolumn{2}{l|}{$\begin{array}{l}\text { Practices regarding the prevention of } \\
\text { dengue fever }\end{array}$} \\
\cline { 2 - 3 } & r & P-value \\
\hline Knowledge about signs and symptoms of dengue fever & 0.458 & $<0.001^{*}$ \\
\hline Knowledge about the mode of transmission & 0.683 & $<0.001^{*}$ \\
\hline Knowledge regarding management of dengue fever & 0.688 & $<0.001^{*}$ \\
\hline Total knowledge & 0.625 & $<0.001^{*}$ \\
\hline
\end{tabular}

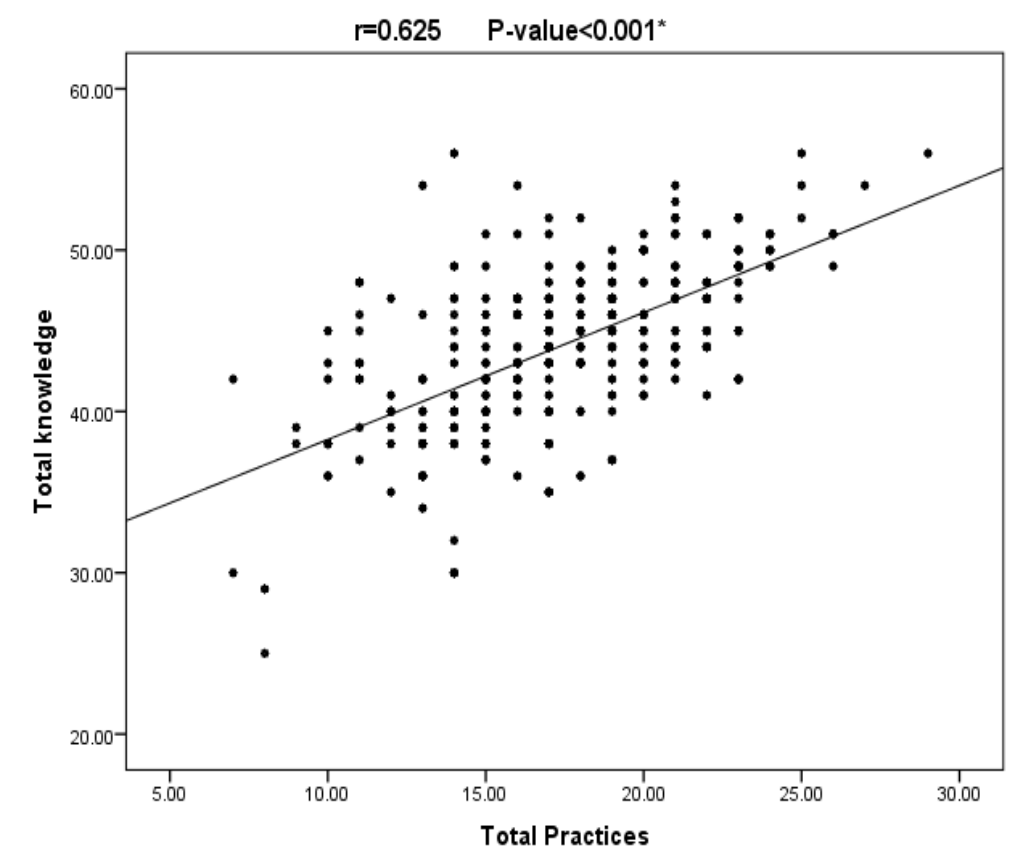

Figure 2: Regression analysis for the correlation between knowledge and practices about dengue fever

Table (4) shows that there is a statistically significant difference between the total practices and patients' sociodemographic characteristics in relation to age, marital status, level of education and income $(p=0.001)$ 
Citation: Hossam Hussen Hijazy, Hosam Wahid Wali, NahlahTulat Haddad, Sadeq Anees Uddinserdar, Rami lbrahim Alamri, Rayan Abdurrahman Alharbi, Moataz Salahaldeen Aljawi, Hamad Nasser Alshareef, Motaz Hussain Alsamli. Knowledge and practice regarding dengue fever among primary health care center patients at KSA. Australian Journal of Basic and Applied Sciences., 13(2): 87-94. DOI: 10.22587/ajbas.2019.13.2.11

Table 4: Significant difference between the level of practices and sociodemographic characteristics:

\begin{tabular}{|c|c|c|c|c|c|c|c|c|}
\hline \multicolumn{2}{|c|}{ Demographic data } & \multirow{3}{*}{$\begin{array}{l}\mathbf{N} \\
60 \\
\end{array}$} & \multicolumn{3}{|c|}{ Total Practices } & \multirow[t]{2}{*}{$\mathbf{F}$ or $\mathbf{T}$} & \multicolumn{2}{|c|}{ ANOVA or T-test } \\
\hline & & & Mean & \pm & SD & & test value & P-value \\
\hline \multirow[t]{4}{*}{ Age } & $15-29$ years & & 16.917 & \pm & 3.729 & \multirow[t]{4}{*}{$\mathrm{F}$} & \multirow[t]{4}{*}{11.250} & \multirow[t]{4}{*}{$<0.001 *$} \\
\hline & 30-44 years & 129 & 17.597 & \pm & 4.019 & & & \\
\hline & 45-59 years & 174 & 19.015 & \pm & 3.661 & & & \\
\hline & More than 60 years & 37 & 17.216 & \pm & 3.802 & & & \\
\hline \multirow[t]{2}{*}{ Gender } & Female & 189 & 17.630 & \pm & 3.658 & \multirow[t]{2}{*}{$\mathrm{T}$} & \multirow[t]{2}{*}{0.011} & \multirow[t]{2}{*}{0.992} \\
\hline & Male & 211 & 17.626 & \pm & 3.946 & & & \\
\hline \multirow{4}{*}{$\begin{array}{l}\text { Marital } \\
\text { status }\end{array}$} & Single & 83 & 19.220 & \pm & 4.171 & \multirow[t]{4}{*}{$\mathrm{F}$} & \multirow[t]{4}{*}{8.450} & \multirow[t]{4}{*}{$<0.001$} \\
\hline & Married & 214 & 17.766 & \pm & 3.820 & & & \\
\hline & Widow & 42 & 16.850 & \pm & 3.538 & & & \\
\hline & Divorced & 61 & 16.210 & \pm & 3.439 & & & \\
\hline \multirow{4}{*}{$\begin{array}{l}\text { Level of } \\
\text { education }\end{array}$} & Illiterate & 96 & 16.015 & \pm & 3.520 & \multirow[t]{4}{*}{$\mathrm{F}$} & \multirow[t]{4}{*}{9.118} & \multirow[t]{4}{*}{$<0.001$} \\
\hline & Primary & 126 & 16.970 & \pm & 3.971 & & & \\
\hline & Secondary & 95 & 17.600 & \pm & 3.517 & & & \\
\hline & University & 83 & 18.550 & \pm & 4.230 & & & \\
\hline \multirow[t]{2}{*}{ Income } & Less than 5000 SR & 163 & 15.150 & \pm & 3.613 & \multirow[t]{2}{*}{$\mathrm{T}$} & \multirow[t]{2}{*}{10.878} & \multirow[t]{2}{*}{$<0.001$} \\
\hline & More than 5000SR & 237 & 19.350 & \pm & 3.914 & & & \\
\hline
\end{tabular}

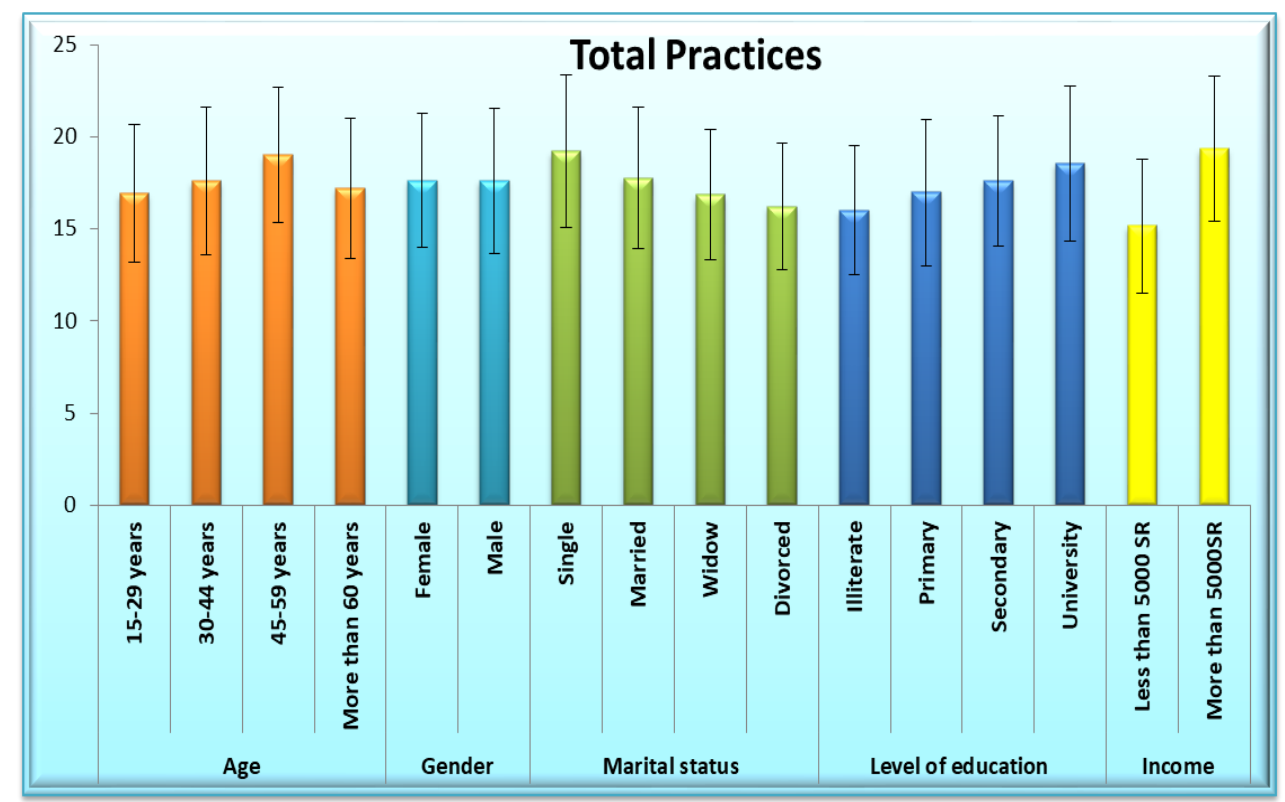

Figure 3: Significant difference between the level of practices and sociodemographic characteristics:

Table (5) shows that there is a statistically significant difference between the total knowledge and patients' sociodemographic characteristics in relation to age, gender, marital status, level of education and income $(\mathrm{p}=0.000)$

Table 5: Significant difference between the level of knowledge and sociodemographic characteristics: 
Citation: Hossam Hussen Hijazy, Hosam Wahid Wali, NahlahTulat Haddad, Sadeq Anees Uddinserdar, Rami lbrahim Alamri, Rayan Abdurrahman Alharbi, Moataz Salahaldeen Aljawi, Hamad Nasser Alshareef, Motaz Hussain Alsamli. Knowledge and practice regarding dengue fever among primary health care center patients at KSA. Australian Journal of Basic and Applied Sciences., 13(2): 87-94. DOI: 10.22587/ajbas.2019.13.2.11

\begin{tabular}{|c|c|c|c|c|c|c|c|c|}
\hline \multicolumn{2}{|c|}{ Demographic data } & \multirow{2}{*}{$\begin{array}{l}\mathbf{N} \\
60\end{array}$} & \multicolumn{3}{|c|}{ Total knowledge } & \multirow{5}{*}{\begin{tabular}{|l|} 
F or $\mathbf{T}$ \\
$\mathrm{F}$ \\
\end{tabular}} & \multicolumn{2}{|c|}{ ANOVA or T-test } \\
\hline \multirow{4}{*}{ Age } & 15-29 years & & \begin{tabular}{|l} 
Mean \\
43.600
\end{tabular} & \pm & $\begin{array}{l}\text { SD } \\
5.397\end{array}$ & & \begin{tabular}{|l|} 
test value \\
8.154 \\
\end{tabular} & $\begin{array}{l}\begin{array}{l}\text { P- } \\
\text { value }\end{array} \\
0.000\end{array}$ \\
\hline & 30-44 years & 129 & 49.000 & \pm & 4.917 & & & \\
\hline & 45-59 years & 174 & 41.220 & \pm & 4.412 & & & \\
\hline & More than 60 years & 37 & 43.510 & \pm & 4.975 & & & \\
\hline \multirow[t]{2}{*}{ Gender } & Female & 189 & 56.540 & \pm & 5.034 & \multirow[t]{2}{*}{$\mathrm{T}$} & \multirow[t]{2}{*}{48.975} & \multirow[t]{2}{*}{0.000} \\
\hline & Male & 211 & 33.000 & \pm & 2.000 & & & \\
\hline \multirow{4}{*}{$\begin{array}{l}\text { Marital } \\
\text { status }\end{array}$} & Single & 83 & 40.540 & \pm & 5.970 & \multirow[t]{4}{*}{$\mathrm{F}$} & \multirow[t]{4}{*}{11.024} & \multirow[t]{4}{*}{0.000} \\
\hline & Married & 214 & 47.110 & \pm & 4.490 & & & \\
\hline & Widow & 42 & 41.110 & \pm & 4.277 & & & \\
\hline & Divorced & 61 & 42.540 & \pm & 4.440 & & & \\
\hline \multirow{4}{*}{$\begin{array}{l}\text { Level of } \\
\text { education }\end{array}$} & Illiterate & 96 & 39.748 & \pm & 4.652 & \multirow[t]{4}{*}{$\mathrm{F}$} & \multirow[t]{4}{*}{0.309} & \multirow[t]{4}{*}{0.819} \\
\hline & Primary & 126 & 40.050 & \pm & 4.857 & & & \\
\hline & Secondary & 95 & 44.215 & \pm & 5.040 & & & \\
\hline & University & 83 & 46.450 & \pm & 4.643 & & & \\
\hline \multirow[t]{2}{*}{ Income } & Less than 5000 SR & 163 & 40.150 & \pm & 4.808 & \multirow[t]{2}{*}{$\mathrm{T}$} & \multirow[t]{2}{*}{14.254} & \multirow[t]{2}{*}{0.000} \\
\hline & More than 5000SR & 237 & 47.115 & \pm & 4.798 & & & \\
\hline
\end{tabular}

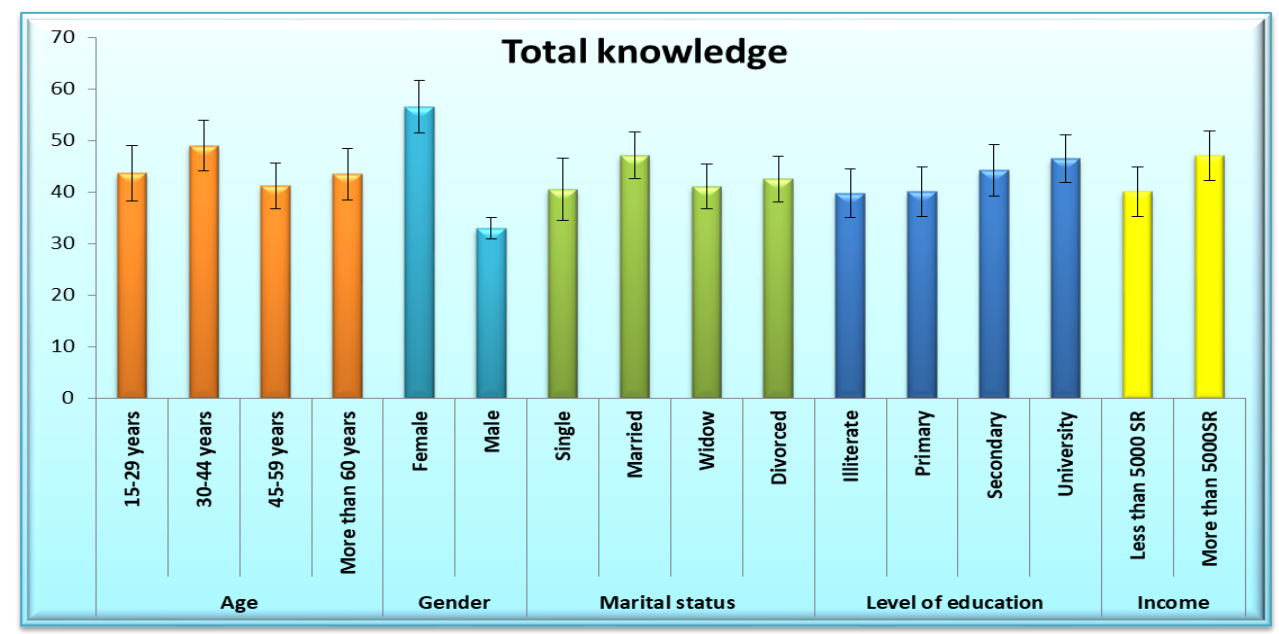

Figure 4: Significant difference between the level of knowledge and sociodemographic characteristics:

\section{DISCUSSION}

Dengue fever is a major arbovirus-borne infectious disease in tropical and subtropical regions of the world. The disease is generally mild and self-limited, but some patients may develop a severe form of infection such as dengue hemorrhagic fever/dengue shock syndrome, which often leads to death. Currently, there is no vaccine available against dengue virus. The major determinants of dengue control are vector eradication, early case recognition, and adequate clinical management (Ho et al., 2013; Handel et al., 2016).

This study reveals that the majority of patients were aged from 30-59 years of age, male, married, illiterate and primary educated. In addition, their source of knowledge about dengue fever were health professionals and television.

This result is in accordance with Malhotra, et al .2014 who found that the majority of study participants were male, married and consider the TV, newspapers and health professionals as the main source of information about dengue fever.

The results of the present study showed the patient has a high and average level of knowledge about signs, symptoms, mode of transmission, and prevention of dengue fever. In addition to the average level of practices regarding the prevention of dengue fever with a statistically significant correlation between knowledge and practice. This result is in opposition with Ho et al, 2013 who conduct a study to assess Knowledge, attitude, and practice of dengue disease among healthcare professionals in southern Taiwan and found a lack of knowledge about important clinical characteristics of dengue.

However, the study results were in the same line with Makornkan et al 2015 who found that Knowledge of DF as reported by the respondents was high, respondents' knowledge of DF prevention and protection was moderate, attitude of DF as reported by the respondents was at a good level, practice of DF prevention as reported by the respondents was at a high level and there was statistical significance between the knowledge and attitude of the respondents and practice of DF prevention.

The results of the present study were supported by ul Akbar, et al. 2015 who found that television is the most important and useful source of information. The adult population of district Swat has adequate knowledge related to the disease "dengue fever". 
Citation: Hossam Hussen Hijazy, Hosam Wahid Wali, NahlahTulat Haddad, Sadeq Anees Uddinserdar, Rami lbrahim Alamri, Rayan Abdurrahman Alharbi, Moataz Salahaldeen Aljawi, Hamad Nasser Alshareef, Motaz Hussain Alsamli. Knowledge and practice regarding dengue fever among primary health care center patients at KSA. Australian Journal of Basic and Applied Sciences., 13(2): 87-94. DOI: 10.22587/ajbas.2019.13.2.11

In addition, the results of the study were far away Dhima, et al. 2014 who conduct a study to assess Knowledge, Attitude and Practice Regarding Dengue Fever among the Healthy Population of Highland and Lowland Communities in Central Nepal. They reveal a low, unsatisfactory level of knowledge about the disease. While being in line with our study finding in relation to the presence of significantly positive correlation among knowledge and practice. Among the socio-demographic variables, the education level of the participants, sex, age, marital status, and income were independent predictors of knowledge level. Education level and interaction between the marital status, income and age group of the participants were independent predictors of practice level.

\section{CONCLUSION}

Primary health care patients consider a very important part of the community and represent public knowledge and practices regarding a certain health issue. Therefore, the result of the study concluded that the patient knowledge regarding dengue fever is high, while there is an average level of practices concerning prevention of dengue fever. They consider health professionals and $\mathrm{TV}$ as the primary sources of information about dengue fever.

\section{RECOMMENDATIONS}

Use of mass media to disseminate more information about dengue fever and more aggressive health education programs with the involvement of health workers and public health professionals so as to ensure that knowledge imparted to the community get translated into practice as well is the emergent need. Replicate this study in other areas and other DHF outbreak areas. Identify strategies that will lead to cooperation among the community.

\section{REFERENCE}

Bhatt S, Gething PW, Brady OJ, Messina JP, Farlow AW, et al. The global distribution and burden of dengue. Nature 496: 504$507 ; 2013$.

Biswas HH, Ortega O, Gordon A, Standish K, et al. Early clinical features of dengue virus infection in Nicaraguan children: a longitudinal analysis. PLoS Negl Trop Dis 2012;6:e1562.

Brady OJ, Gething PW, Bhatt S, et al. Refining the global spatial limits of dengue virus transmission by evidence-based consensus. PLoS Negl Trop Dis 6:e1760(2012).

CDC, Centers for Disease Control and Prevention. Dengue fever. Colorado: 2008. [updated 2008; cited October 18, 2008]; Available from: http://www.cdc.gov/ncidod/dvbid/dengue/

Chang K, Lu PL, Ko WC, et al. Dengue fever scoring system: a new strategy for the early detection of acute dengue virus infection in Taiwan. J Formos Med Assoc 2009; 108:879e85.

Dhimal M, Aryal KK, et al. Knowledge, Attitude and Practice Regarding Dengue Fever among the healthy population of Highland and Lowland Communities in Central Nepal. PLoS ONE. 2014 9(7)

Hales S, Maindonald J, Woodward A. Potential effect of population and climate changes on global distribution of dengue fever: an empirical model. Lancet 2002;360(9336):830. [PubMed: 12243917]

Halstead S. Dengue. Lancet. 2007;370 (9599):1644-52.

Handel A, Ayala E, et al. Knowledge, attitudes, and practices regarding dengue infection among public sector healthcare providers in Machala, Ecuador. Tropical Diseases, Travel Medicine and Vaccines (2016) 2:8

Handel AS, Ayala EB, Borbor-Cordova MJ, et al. Knowledge, attitudes, and practices regarding dengue infection among public sector healthcare providers in Machala, Ecuador. Tropical Diseases, Travel Medicine and Vaccines (2016) 2:8

Heyman, DL. American Public Health Association APHA. Communicable Diseases Manual. 19. Washington, DC: 2008.

HoT, Huang M, et al. Knowledge, attitude, and practice of dengue disease among healthcare professionals in southern Taiwan. Journal of the Formosan Medical Association (2013) 112, $18 \mathrm{e} 23$.

Hotez PJ, Bottazzi ME, Franco-Paredes C, Ault SK, Periago MR. The neglected tropical diseases of Latin America and the Caribbean: a review of disease burden and distribution and a roadmap for control and elimination. PLoS Negl Trop Dis. 2008; 2(9):e300.

Itrat A, Khan A, Javaid S, Kamal M, Khan H, et al. (2008) Knowledge, Awareness and Practices Regarding Dengue Fever among the Adult Population of Dengue Hit Cosmopolitan. PLoS ONE 3(7)

Laoprasopwattana K, Kaewjungwad L, Jarumanokul R, et al. Differential diagnosis of Chikungunya, dengue viral infection and other acute febrile illnesses in children. Pediatr Infect Dis J 2012;31:459e63.

Lee L, Thein T, et al. Dengue Knowledge, Attitudes, and Practices among Primary Care Physicians in Singapore. Ann Acad Med Singapore 2011;40:533-8.

Leong A, Wong K, Leong T, Tan P, Wannakrairot P. The pathology of dengue hemorrhagic fever. Seminars in Diagnostic Pathology 2007;24(4):227-36. [PubMed: 18085063]

Makornkan S, Saminpanya P, et al. Knowledge, Attitude and Practice of Dengue Fever Prevention Among the Villagers of Moo 1 Baan Klongsai, Nhongyangsuea Subdistrict, Muaklek District, Saraburi Province, Thailand. Catalyst. Volume 12, No. 2, 2015

Malavige GN, Fernando S, Fernando DJ, et al. Dengue viral infections. Postgrad Med J 2004;80:588e601.

Malhotra V, Kaur P. The Community knowledge, attitude and practices regarding Dengue fever infield practice area of urban training health center of Patiala. Int J Res Dev Health. March 2014; Vol 2(1): 19-26

NALONGSACK S, YOSHIDA Y, MORITA S, Et al. KNOWLEDGE, ATTITUDE, AND PRACTICE REGARDING DENGUE AMONG PEOPLE IN PAKSE, LAOS. J. Med. Sci. 71. 29 37, 2009. 
Nasir NH, Mohamad M, Lum LC, et al. Effectiveness of a fluid chart in outpatient management of suspected dengue fever: A pilot study. PLoS ONE 12(10): e0183544. https://doi. org/10.1371/journal.pone.0183544

Pai H, Lu Y, Hong Y, Hsu E. The differences of dengue vectors and human behavior between families with and without members having dengue fever/dengue hemorrhagic fever. International Journal of Environmental Health Research 2005;15(4):263-9.

Premaratna R, Pathmeswaran A, Amarasekara ND, et al. A clinical guide for early detection of dengue fever and timing of investigations to detect patients likely to develop complications. Trans R Soc Trop Med Hyg 2009;103:127e31.

Ramos MM, Tomashek KM, Arguello DF, et al. Early clinical features of dengue infection in Puerto Rico. Trans R Soc Trop Med Hyg 2009;103: 878e84.

Shuaib F, Todd D, Campbell-Stennett, et al. Knowledge, attitudes and practices regarding dengue infection in Westmoreland, Jamaica. West Indian Med J. 2010; 59(2): 139-146.

Tzong-Shiann, Mei-Chih Huang, Shih-Min Wang, et al. Knowledge, attitude, and practice of dengue disease among healthcare professionals in southern Taiwan. Journal of the Formosan Medical Association (2013) 112, 18e23

ul Akbar N, Ullah K, et al. Awareness, Knowledge, and Practices Regarding Dengue Fever among the Adult Population of Dengue Hit Cosmopolitan Three Different Hospitals Located in District Swat. World Applied Sciences Journal 33 (9): 1522-1527, 2015.

WHO, Geneva. Dengue and dengue hemorrhagic fever. Geneva: WHO; 2009. [updated March,2009; cited October 31, 2009]; Available from: http://www.who.int/mediacentre/factsheets/fs117/en/

WHO/TDR (2009) Dengue: guidelines for diagnosis, treatment, prevention, and control. Geneva: World Health Organization (WHO) and the Special Programme for Research and Training in Tropical Diseases (TDR). 